\title{
Indian Ocean Hydrothermal Systems: Seafloor Hydrothermal Activities, Physical and Chemical Characteristics of Hydrothermal Fluids, and Vent-Associated Biological Communities
}

\author{
Kentaro Nakamura and Ken Takai
}

\begin{abstract}
In the nearly 40 years since the discovery of the deep-sea hydrothermal vent site at the Galápagos spreading center, more than 300 sites of high-temperature hydrothermal venting have been discovered and investigated around the world. Surprisingly, however, most of these sites are located in the Pacific and Atlantic Oceans, whereas only five hydrothermal vent sites have been discovered in the Indian Ocean. During the TAIGA project, we conducted four research cruises to investigate four of the five Indian Ocean hydrothermal vent sites (two of which were newly discovered during one of the TAIGA cruises) located along the Central Indian Ridge (CIR). The results of geological and geochemical analyses demonstrate wide variation in fluid chemistry, reflecting the diverse geological background of the CIR hydrothermal vent fields. Although the CIR is an intermediate-spreading ridge, the geological and geochemical features of the Kairei hydrothermal field appear to be similar to ultramafic rock-hosted hydrothermal fields found along the slow-spreading Mid-Atlantic Ridge (MAR). By contrast, the Dodo hydrothermal field shares similarities with the hydrothermal vent sites found along the fast-spreading East Pacific Rise. The Solitaire and Edmond hydrothermal fields are characterized by high $\mathrm{pH}$ and $\mathrm{Cl}$ levels, respectively, although the geological background underlying the unusual chemistry of their hydrothermal fluids is still uncertain. Additionally, extensive microbiological analyses of the Kairei hydrothermal vent site revealed that its microbial communities are affected by the chemical characteristics of the hydrothermal vent fluids. Macrofaunal analyses also revealed new faunal data for the Indian Ocean hydrothermal vents, including novel genera and families that are potentially indigenous to the Indian Ocean hydrothermal systems. In particular, the discovery and characterization of a new morphotype of "scaly-foot" gastropod raises the question of the mechanism and physiological role of iron sulfide mineralization. The results of our investigations extended knowledge of the Indian Ocean hydrothermal systems including geochemical variations of hydrothermal fluids, their relationships to the geological
\end{abstract}

K. Nakamura $(\bowtie)$

Precambrian Ecosystem Laboratory (PEL), Japan Agency for MarineEarth Science and Technology (JAMSTEC), 2-15 Natsushima, Yokosuka, Kanagawa 237-0061, Japan

Submarine Hydrothermal System Research Group, Japan Agency for Marine-Earth Science and Technology (JAMSTEC), 2-15 Natsushima, Yokosuka, Kanagawa 237-0061, Japan

Present address: Department of Systems Innovation, School of Engineering, The University of Tokyo, 7-3-1 Hongo, Bunkyo-ku, Tokyo 113-8656, Japan

e-mail: kentaron@sys.t.u-tokyo.ac.jp

\section{K. Takai}

Precambrian Ecosystem Laboratory (PEL), Japan Agency for MarineEarth Science and Technology (JAMSTEC), 2-15 Natsushima, Yokosuka, Kanagawa 237-0061, Japan

Submarine Hydrothermal System Research Group, Japan Agency for Marine-Earth Science and Technology (JAMSTEC), 2-15 Natsushima, Yokosuka, Kanagawa 237-0061, Japan

Subsurface Geobiology Advanced Research (SUGAR) Project, Japan Agency for Marine-Earth Science and Technology (JAMSTEC), 2-15 Natushima-cho, Yokosuka, Kanagawa 237-0061, Japan 
background, the biodiversity and biogeography of the hydrothermal vent-associated microbial and faunal communities. This, in turn, will provide important insight into the relationships among geological backgrounds, hydrothermal processes, and biological activities, not only at the Indian Ocean hydrothermal vents but also in global midocean ridge hydrothermal systems.

Keywords

Biodiversity • Fluid chemistry • Geological background • Hydrothermal system • Indian

Ocean $\cdot$ Scaly-foot

\subsection{Introduction}

Since the discovery of deep-sea hydrothermal vents at the Galápagos Rift in 1977 (Corliss et al. 1979), mid-ocean ridge (MOR) hydrothermal systems have attracted attention as key phenomena driving the geochemical cycles of many elements and sustaining unique biological communities in the ocean. A number of geological, geochemical, and biological studies have been conducted at MOR hydrothermal vent sites, providing important insight into the effect of MOR hydrothermal activity on ocean chemistry (e.g., Edmond et al. 1979, 1982; Von Damm et al. 1985a, b; Palmer and Edmond 1989; Elderfield and Schultz 1996), the limit, origin, and early evolution of life (e.g., (Jannasch and Mottl 1985; Nealson et al. 2005; Takai et al. 2006; Takai 2011) as well as the diversity and connections among different biogeographical provinces of hydrothermal vent faunas (e.g., Van Dover et al. 2002; Bachraty et al. 2009; Vrijenhoek 2010). However, most of the hydrothermal vent sites discovered and investigated thus far are located in the Pacific and Atlantic Oceans (German and Von Damm 2004), whereas only a few hydrothermal fields have been identified in the Indian Ocean (Gamo et al. 2001; Hashimoto et al. 2001; Van Dover et al. 2001; Tao et al. 2012; Nakamura et al. 2012). Thus, the geological, geochemical, and biological features of the Indian Ocean hydrothermal system remain poorly understood, and it appears highly uncertain which features are common to global hydrothermal systems and which are unique to the Indian Ocean system.

From 2008 to 2013, an interdisciplinary project (the TAIGA project) focused on interactions between the lithosphere, hydrosphere, and biosphere through the fluid circulation system beneath the seafloor was pursued (Urabe et al. Chap. 1). In this project, the Indian Ocean hydrothermal system was recognized as a major target because, at the beginning of the project, the geological, geochemical, and biological features of the Indian Ocean hydrothermal vent sites were observed to be quite diverse, even though they are located within the quite limited area of the Central Indian Ridge (CIR). In addition, this diversity appeared to be driven by different linkages among geological, geochemical, and biological features (Urabe et al. Chap. 1). During this project, four research cruises using the R/V Yokosuka, R/V Hakuho-maru, human-occupied vehicle (HOV) Shinkai 6500, and autonomous underwater vehicle (AUV) r2D4 were conducted to investigate the hydrothermal systems of the Indian Ocean. The cruises successfully discovered and explored two new hydrothermal vent sites (the Dodo and Solitaire hydrothermal fields) along the CIR and obtained additional detailed information on the two previously known hydrothermal vent systems (Kairei and Edmond hydrothermal fields). In this paper, we summarize the results of the investigations conducted in these Indian Ocean hydrothermal systems.

\subsection{The Four Indian Ocean Hydrothermal Vent Fields Studied in the TAIGA Project}

The four hydrothermal vent fields situated along the CIR (the Dodo, Solitaire, Edmond, and Kairei fields) (Fig. 12.1) were studied in the TAIGA project. The Edmond and Kairei hydrothermal fields were discovered previously (Gamo et al. 2001; Hashimoto et al. 2001; Van Dover et al. 2001), whereas the Dodo and Solitaire hydrothermal fields were newly discovered during the TAIGA project (Nakamura et al. 2012). Geological settings and geochemical characteristics of the four hydrothermal vent fields are summarized in Table 12.1.

\subsubsection{Dodo Hydrothermal Field}

The Dodo hydrothermal field $\left(18^{\circ} 20.1^{\prime} \mathrm{S}, 65^{\circ} 17.9^{\prime} \mathrm{E}\right.$; depth of $2,745 \mathrm{~m}$ ) is located in the Dodo Great Lava Plain in the middle of CIR segment 16 (Fig. 12.2a) (Nakamura et al. 2012). In this field, the active vents are situated on the spreading axis (Fig. 12.2b), in contrast to the hydrothermal vents of the other three hydrothermal vent fields (Solitaire, Kairei, and Edmond), which are all located in the off-axis region. The existence of seafloor hydrothermal activity in 


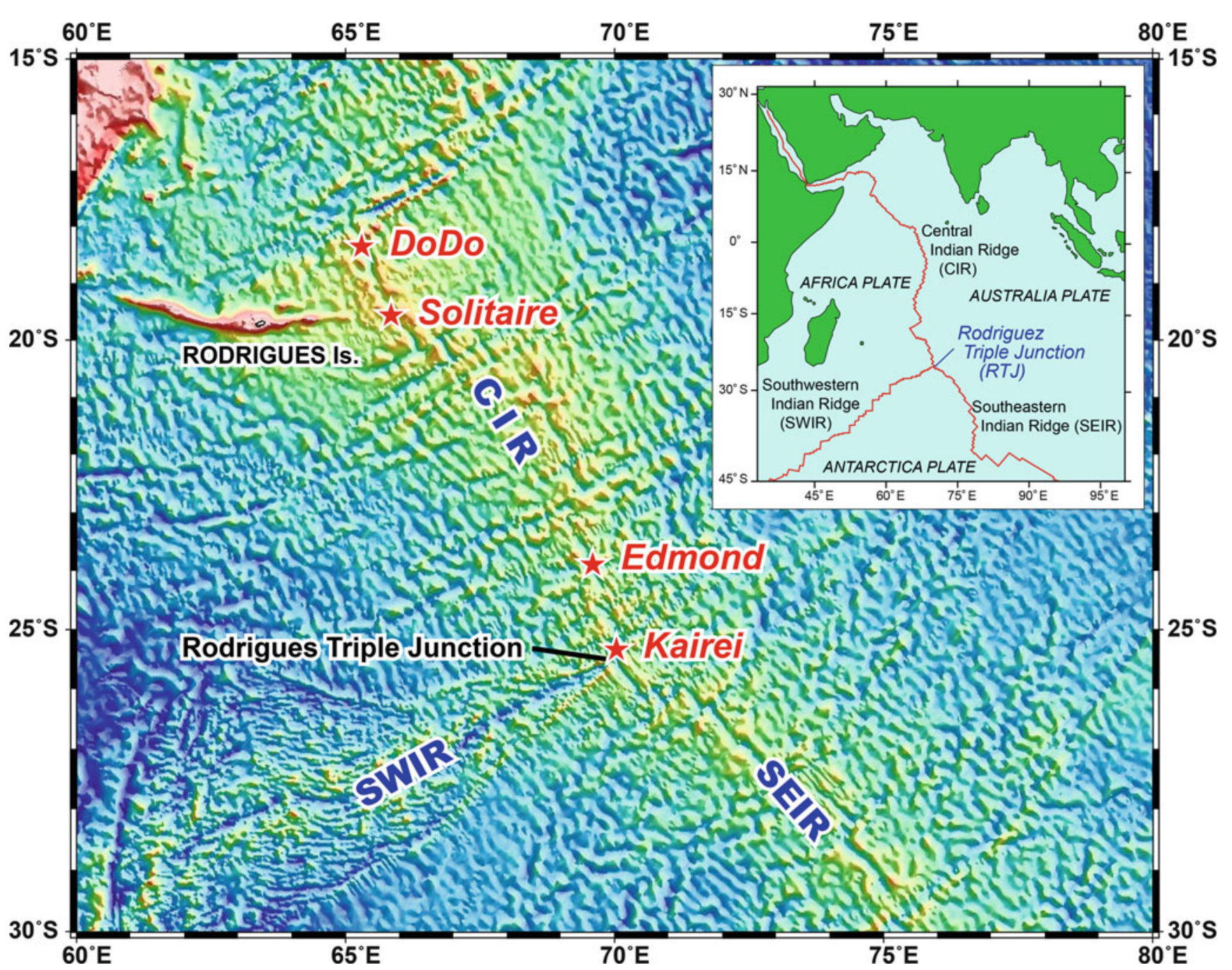

Fig. 12.1 Index map showing the locations of the four hydrothermal vent fields (Dodo, Solitaire, Edmond, and Kairei) along the Central Indian Ridge (CIR)

Table 12.1 Location, host-rock type, and hydrothermal fluid chemistry of the four CIR hydrothermal vent fields

\begin{tabular}{lllll}
\hline Hydrothermal field & Dodo & Solitaire & Edmond & Kairei \\
\hline Location & CIR-segment16 on-axis & CIR-segment15 off-axis & CIR-segment4 off-axis & CIR-segment1 off-axis \\
\hline Host-rock type & E-MORB & E-MORB & N-MORB & Troctolite + D-MORB \\
\hline Depth $(\mathrm{m})$ & 2,745 & 2,606 & $3,270-3,303$ & $2,420-2,452$ \\
\hline Temperature $\left({ }^{\circ} \mathrm{C}\right)$ & 356 & 296 & 382 & 369 \\
\hline $\mathrm{pH}\left(25{ }^{\circ} \mathrm{C}\right)$ & 3.2 & 4.8 & $\leq 2.97-3.3$ & $3.35-3.60$ \\
$\mathrm{Cl}(\mathrm{mmol} / \mathrm{L})$ & $\sim 680$ & $\sim 500$ & $926-973$ & $571-623$ \\
\hline $\mathrm{H}_{2}(\mathrm{mmol} / \mathrm{L})$ & $\sim 2.4$ & 0.46 & $0.0556-0.1116$ & $2.48-8.50$ \\
\hline $\mathrm{CH}_{4}(\mathrm{mmol} / \mathrm{L})$ & $\sim 0.02$ & $\sim 0.05$ & $0.233-0.415$ & $0.123-0.203$ \\
\hline $\mathrm{CO}_{2}(\mathrm{mmol} / \mathrm{L})$ & $\sim 4$ & $\sim 8$ & $7.19-15.8$ & $4.53-10.1$ \\
\hline References & 1 & 1 & 2,3 & $2,3,4$ \\
\hline
\end{tabular}

$C I R$ central indian ridge, $M O R B$ mid-ocean ridge basalt, $E$-MORB enriched MORB, $N$-MORB normal MORB, $D$-MORB depleted MORB

1. Nakamura et al. (2012), 2. Gallant and Von Damm (2006), 3. Kumagai et al. (2008), 4. Van Dover et al. (2001) 

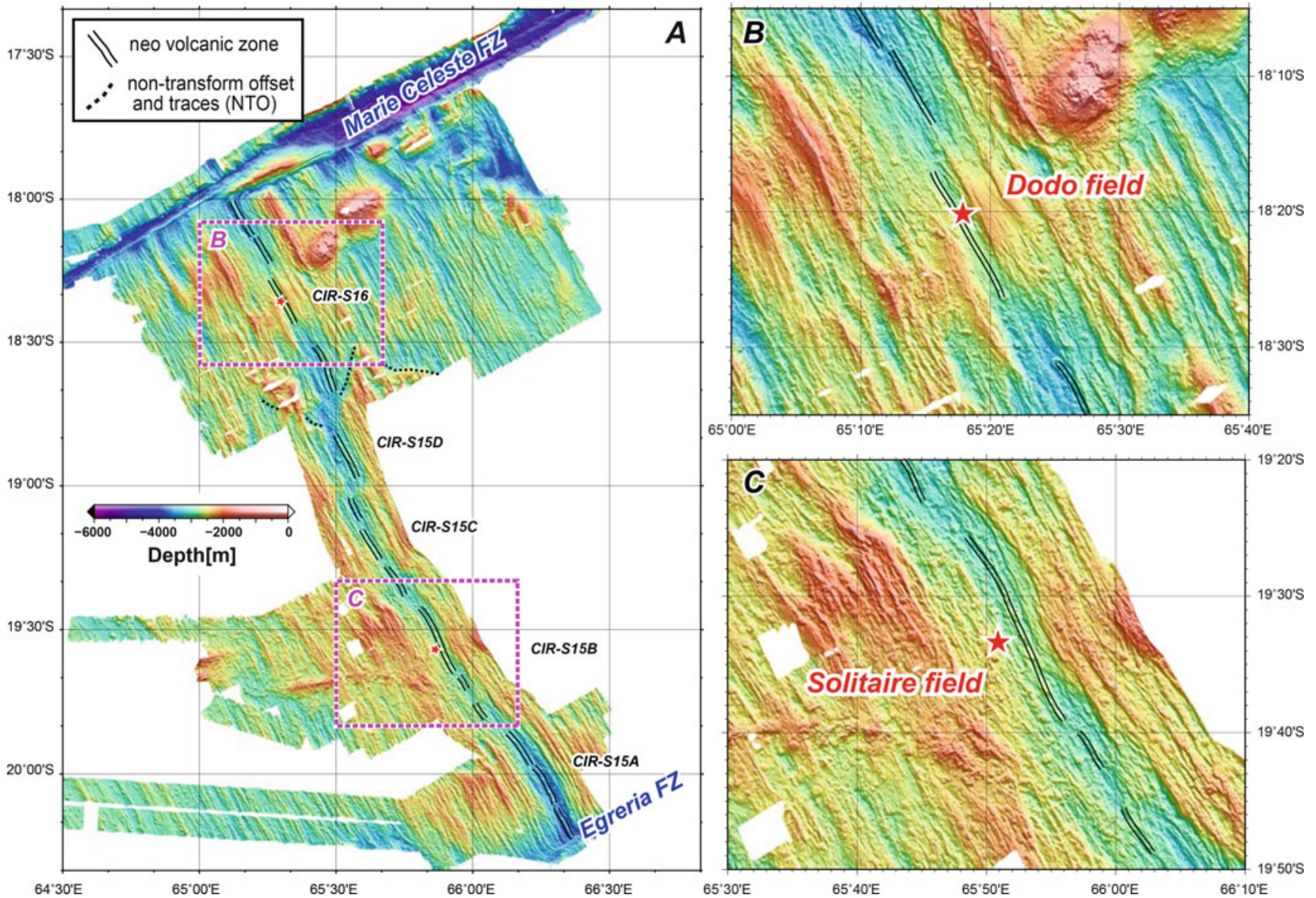

Fig. 12.2 (a) Bathymetric map of the Rodriguez segment area and detailed bathymetry maps around the (b) Dodo and (c) Solitaire hydrothermal fields (after Okino et al. Chap. 11)

the area situated from $18-20^{\circ} \mathrm{S}$ on the CIR had been suggested by two previous surveys that detected hydrothermal anomalies in the water column (Jean-Baptiste et al. 1992; German et al. 2001). In December 2006, an extensive plume survey was conducted in the CIR region approximately $19^{\circ} \mathrm{S}$ during the $\mathrm{KH} 06-4$ cruise on the R/V Hakuho-maru using vertical and tow-yo hydrocasts and the AUV r2D4. During the survey, evident plume signatures of hydrothermally derived $\mathrm{CH}_{4}, \mathrm{Mn}$, and ${ }^{3} \mathrm{He}$ abundance anomalies and a light transmission signal anomaly were detected in a ridge axial valley of the CIR at $18^{\circ} 20^{\prime}$ 'S within the Dodo Great Lava Plain (Kawagucci et al. 2008). Three years later, in October 2009, detailed observations of the seafloor were performed using a deeptow camera and the HOV Shinkai 6500 during the YK 09-13 cruise on the R/V Yokosuka. During the cruise, a new hydrothermal field, named the Dodo hydrothermal field, was discovered (Nakamura et al. 2012). The Dodo Great Lava Plain, hosting the Dodo hydrothermal field, is characterized by a flat, smooth seafloor covered with sheet flow lavas stretching over $10 \mathrm{~km}$ along the axis, suggestive of high production rates of basaltic melt. These morphological features are similar to those of typical fastspreading ridges, such as the East Pacific Rise (EPR), rather than that in the spreading centers of the other CIR segments characterized by intermediate spreading rates.

Hydrothermal fluid emissions were observed within a small area ( $\sim 15 \mathrm{~m}$ in diameter) in which many small black smoker chimneys (less than $1 \mathrm{~m}$ in height) sprout directly from cracks in the basaltic sheet flow lava. Three main chimney sites were observed: Potsunen, Tsukushi-1, and Tsukushi-2, among which the most vigorous black smoker discharges were observed at the Tsukushi-2 chimney site (Fig. 12.3a). Clear, diffuse fluid flows, either from tiny chimneys or directly from cracks and crevices in the basaltic sheet flow lava, were also detected around the black smoker chimneys. In addition to the active chimneys, several inactive chimneys were found near the Tsukushi- 2 chimney site. Interestingly, there are many brownish spots with a small, collapsed crater-like structure on the basaltic sheet flow lava surrounding the hydrothermal vent sites (Fig. 12.3b), and cracks or crevices in pillowed lava and in the interpillow spaces are also stained a brownish color (Fig. 12.3c). The stained area extends more than $50 \mathrm{~m}$ along the $\mathrm{N}-\mathrm{S}$ axis and 
Fig. 12.3 Photographs of (a) the Tsukushi-2 chimneys on basaltic sheet flow lava at the Dodo hydrothermal field; (b) a brownish spot in the collapsed sheet flow lava; (c) cracks and interpillow spaces stained a brownish color; (d) inactive chimneys at the Tsukushi2 chimney site without any fauna present, observed at the Dodo hydrothermal field in 2013; (e) the Toukon-3 chimneys in the Solitaire hydrothermal field; (f) a diffuse flow area issuing clear fluids in the Solitaire hydrothermal field; (g) large black smoker chimneys at the Nura Nura vent site, in the Edmond hydrothermal field; and (h) a small black smoker chimney at the Kali vent site, in the Kairei hydrothermal field
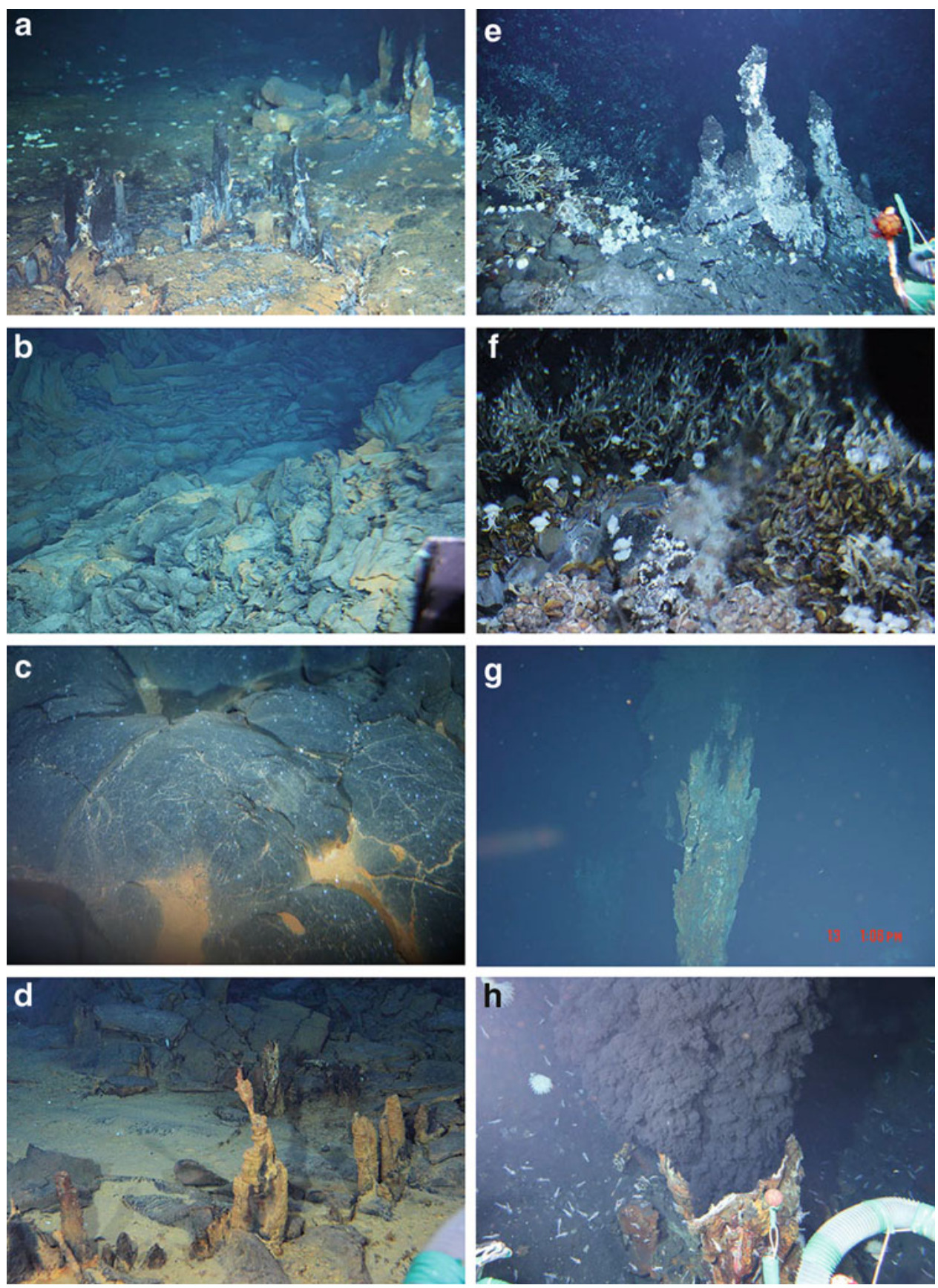

at least $200 \mathrm{~m}$ along the $\mathrm{E}-\mathrm{W}$ axis. Recent observations made on the HOV Shinkai 6500 in 2013 revealed that obvious hydrothermal fluid discharges at the Dodo field had stopped (Fig. 12.3d).

\subsubsection{Solitaire Hydrothermal Field}

The Solitaire hydrothermal field $\left(19^{\circ} 33.413 \mathrm{~S}, 65^{\circ} 50.888 \mathrm{E}\right.$; at a depth of 2,606 m) is located on the Roger plateau on the western ridge flank of CIR segment 15 , at approximately $19^{\circ} 33^{\prime} \mathrm{S}$ (Fig. 12.2a), several kilometers from the ridge axis (Fig. 12.2c) (Nakamura et al. 2012). The location of the Solitaire hydrothermal field is approximately $150 \mathrm{~km}$ south of the Dodo hydrothermal field. As for the Dodo field, during the KH 06-4 cruise on the R/V Hakuho-maru in December 2006, an extensive plume survey was conducted using vertical and tow-yo hydrocasts and the AUV r2D4 in the area where the existence of hydrothermal activity had been suggested by previous studies (Jean-Baptiste et al. 1992; German et al. 2001). During the survey, evident plume signatures of anomalies hydrothermally derived $\mathrm{CH}_{4}, \mathrm{Mn}$ 

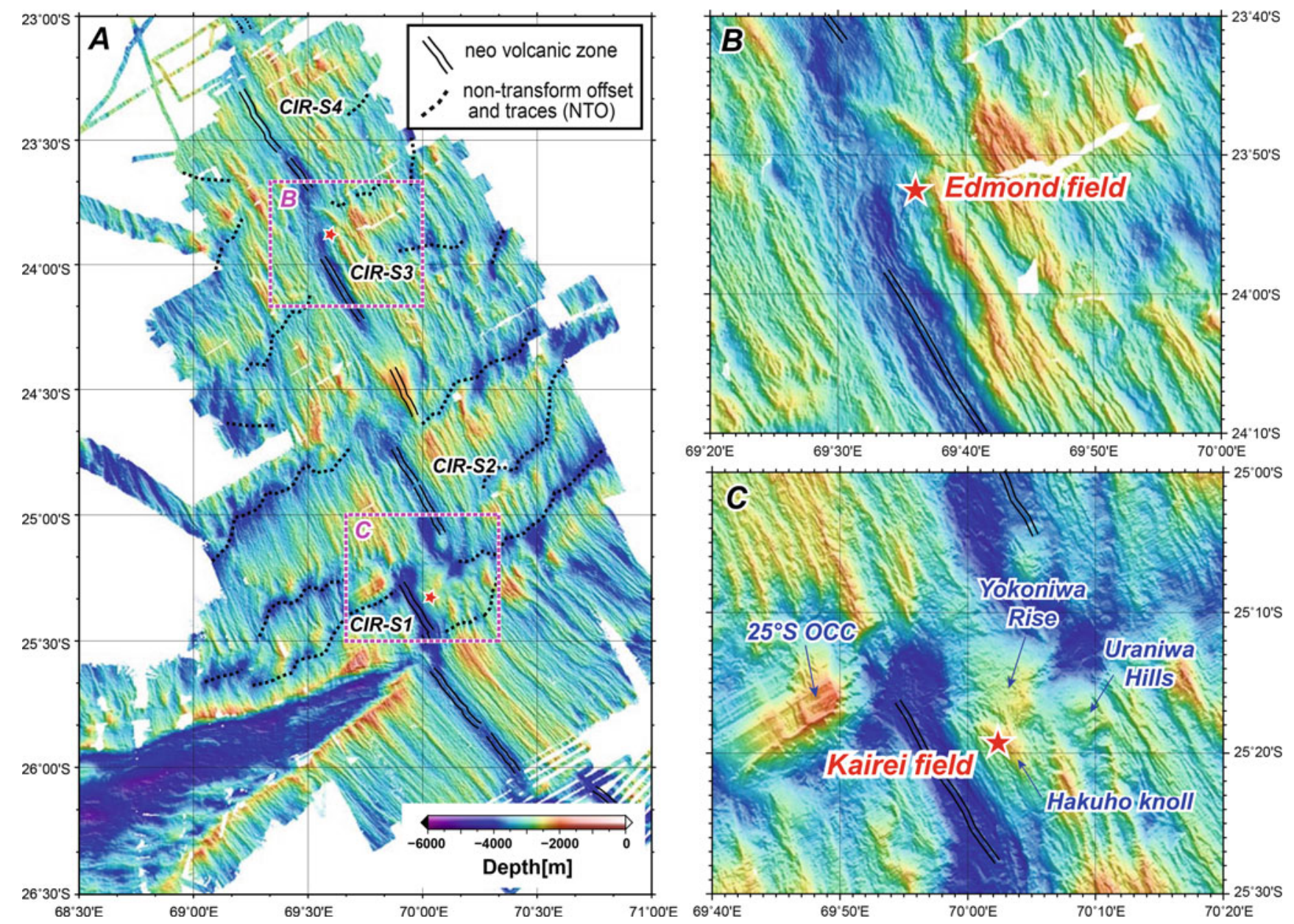

Fig. 12.4 (a) Bathymetric map of the CIR-S1 to S4 area and detailed bathymetry maps around the (b) Edmond and (c) Kairei hydrothermal fields (after Okino et al. Chap. 11).

and ${ }^{3} \mathrm{He}$ abundance and a light transmission signal anomaly were detected along the western off-axis slope of the CIR, at $19^{\circ} 34^{\prime} \mathrm{S}$, on the Roger Plateau (Kawagucci et al. 2008). Finally, in October 2009, during the YK 09-13 cruise of the R/V Yokosuka, a new seafloor hydrothermal vent site, designated the Solitaire hydrothermal field, was discovered through deep-tow camera surveys and HOV dive observations.

The Solitaire field is situated on the talus at the base of a NNW-SSE-trending steep cliff regarded as a fault scarp. The area of hydrothermal fluid emissions was found to be approximately $50 \times 50 \mathrm{~m}$, which is significantly larger than the active venting area of the Dodo hydrothermal field but slightly smaller than those of the Kairei and Edmond hydrothermal fields. In the Solitaire hydrothermal field, three major chimney sites (Toukon-3, Tenkoji, and Liger) were identified. The observed chimneys were less than $5 \mathrm{~m}$ in height, with small mounds at their feet (Fig. 12.3e). Although several black smoker discharges were observed at the top of the Toukon-3 chimneys, most of the identified hydrothermal emissions in the Solitaire field consist of clear fluids. In particular, numerous diffuse flow areas issuing clear fluids directly from the talus are a characteristic feature of the Solitaire field (Fig. 12.3f). It is likely that the extensive occurrence of thick and highly permeable talus results in a broad range of mixing zones in the subseafloor environments between the upwelling hydrothermal fluids and the infiltrated seawater.

\subsubsection{Edmond Hydrothermal Field}

The Edmond hydrothermal field $\left(23^{\circ} 52.68^{\prime} \mathrm{S}, 69^{\circ} 35.80^{\prime} \mathrm{E}\right.$; at depths of 3,290-3,320 m) is located at the northern end of CIR segment 3 (Fig. 12.4a) (Van Dover et al. 2001). The location of the Edmond hydrothermal field is approximately $1,000 \mathrm{~km}$ south of the Solitaire hydrothermal field. The presence of active seafloor vents in this region was suggested by the results of hydrothermal plume surveys conducted in the 1980s (Herzig and Plüger 1988; Plüger et al. 1990). In 
April 2001, detailed geological investigations were conducted through near-bottom water-column surveys by an American research team using the R/V Knorr and the remotely operated vehicle (ROV) Jason. The investigation resulted in the successful discovery of a hydrothermal vent field in an off-axis region of CIR segment 3 (Van Dover et al. 2001), where typical abyssal hills are observed (Kumagai et al. 2008) (Fig. 12.4b).

The main area of hydrothermal venting in the Edmond hydrothermal field covers $\sim 100 \times 60 \mathrm{~m}$ (Gallant and Von Damm 2006), which is larger than the other known CIR hydrothermal fields. The black smoker complexes are also larger (up to $35 \mathrm{~m}$ tall and $2 \mathrm{~m}$ in diameter; Gallant and Von Damm 2006) than any other known CIR hydrothermal field. The most vigorous black-smoker venting is located in discrete clusters of large chimneys at the Nura Nura vent site (Fig. 12.3g) (Kumagai et al. 2008). Similar to the Solitaire hydrothermal field, extensive areas of diffuse flows are present in the Edmond hydrothermal field, suggesting subseafloor seawater entrainment and mixing processes over a broad area. In addition to sulfide structures, orangebrown, iron oxyhydroxide sediments are also commonly observed around the Edmond hydrothermal field.

\subsubsection{Kairei Hydrothermal Field}

The Kairei hydrothermal field is located in the first segment of the CIR $\left(25^{\circ} 19.23^{\prime} \mathrm{S}, 70^{\circ} 02.42^{\prime} \mathrm{E}\right.$; at a depth of 2,415-2,460 m) (Fig. 12.4a) (Gamo et al. 2001). The hydrothermal field was first recognized in 1993 through CTD hydrocasts and tow-yo surveys (Gamo et al. 1996) and was finally discovered by the ROV Kaiko in August 2000 as the first hydrothermal vent site in the Indian Ocean (Gamo et al. 2001). Based on the chemical characteristics of the detected hydrothermal vent fluids as well as basaltic rocks recovered in the vicinity of the hydrothermal vent field, the Kairei hydrothermal field was first recognized as a typical midocean ridge basalt (MORB)-hosted hydrothermal system, despite the unusually high concentrations of $\mathrm{H}_{2}$ found in its hydrothermal fluids (Gamo et al. 2001; Van Dover et al. 2001; Gallant and Von Damm 2006). However, subsequent bathymetric and visual observations performed using the R/ V Yokosuka and HOV Shinkai 6500 revealed that there are two well-defined oceanic core complex (OCC) structures (the $25^{\circ} \mathrm{S}$ OCC and Uraniwa Hills) consisting of peridotitic and gabbroic rocks within $20 \mathrm{~km}$ of the Kairei field (Kumagai et al. 2008) (Fig. 12.4c). More recent observations identified another peridotite-gabbro massif, designated the Yokoniwa Rise, just north of the Hakuho Knoll (Fig. 12.4c). Interestingly, it is generally accepted that OCCs occur only in slow- to ultra-slow-spreading ridges under magmastarved conditions (Escartin et al. 2003; Cannat et al.
2006), whereas the CIR has been classified as an intermediate-spreading ridge with a spreading speed of $47.5 \mathrm{~mm} /$ year (DeMets et al. 1994).

The main area of high-temperature vents extends for $\sim 80 \mathrm{~m}$ along the rift wall and is $\sim 40 \mathrm{~m}$ wide (Gamo et al. 2001; Gallant and Von Damm 2006). Several black smoker complexes with a maximum height of $>10 \mathrm{~m}$ have been recognized in this area. The most vigorous black smoker discharges were observed at the Kali vent site (Fig. 12.3h) (Kumagai et al. 2008) in the westernmost part of the Kairei hydrothermal field. Although diffuse, lower-temperature flows along the sides and bases of black smoker chimneys are often detectable, broad areas of low-temperature simmering have not been observed in this hydrothermal field. In addition to the large active black smoker chimneys, large accumulations of weathered sulfides and inactive chimneys were also observed in this hydrothermal field.

\subsection{Physical and Chemical Characteristics of Hydrothermal Fluids}

In the Dodo hydrothermal field, the highest temperature measured was $356{ }^{\circ} \mathrm{C}$, at the Tsukushi-2 chimney site. The lowest $\mathrm{pH}$ level of 3.2 was also recorded at this chimney site. These temperature and $\mathrm{pH}$ values are comparable with those of typical MOR black smoker fluids (German and Von Damm 2004). The $\mathrm{Cl}$ concentration in the hydrothermal fluid was found to be significantly $(\sim 20 \%)$ enriched from that in seawater, suggesting subseafloor phase-separation and brine-phase enrichment. A notable feature of the Dodo hydrothermal fluids is their unusually high concentration of $\mathrm{H}_{2}(>2 \mathrm{mmol} / \mathrm{L})$. Such high $\mathrm{H}_{2}$ contents in hydrothermal fluids are more similar to those found in ultramafic rockhosted hydrothermal fluids (e.g., in the Rainbow, Logatchev, and Kairei fields), rather than basalt-hosted fluids. However, the morphological features of the Dodo Great Lava Plane clearly suggest a high production rate of basaltic melt, and indeed, no ultramafic rock has been identified around the Dodo hydrothermal field. Kawagucci et al. (2008) suggested a possible involvement of ultramafic rocks exposed in the Marie Celeste Fracture Zone (Hekinian 1982), approximately $50 \mathrm{~km}$ north of the Dodo hydrothermal field (Fig. 12.1). Although a model with large-scale hydrothermal circulation is not consistent with the fluid circulation pattern expected for the Dodo field (potentially an EPR-type, shortlived, relatively shallow circulating system), future investigations will be needed to determine the role of large fracture zones in the hydrothermal activity (especially in terms of fluid chemistry) of the neighboring segments. Conspicuous enrichment of $\mathrm{K}$ relative to $\mathrm{Cl}$ is also a distinctive feature commonly observed in the fluids of the Dodo field (Nakamura et al. 2012). It has been reported that the 
basement MORB of the Dodo and Solitaire hydrothermal fields is highly enriched in alkaline and alkaline earth elements compared with typical MORB, due to the influence of plume components derived from the Réunion hot spot (Murton et al. 2005; Nauret et al. 2006). Therefore, it is reasonable to consider the high $\mathrm{K} / \mathrm{Cl}$ ratio and, likely, other alkali element-to- $\mathrm{Cl}$ ratios of the Dodo hydrothermal fluids to reflect the distinct chemistry of the plume-influenced MORB at the base of the hydrothermal field.

In the Solitaire hydrothermal field, a significantly higher $\mathrm{pH}$ (4.8) was observed compared to the $\mathrm{pH}$ values of typical MOR hydrothermal fluids $(3.3 \pm 0.5)$ (German and Von Damm 2004). To explain the relatively high $\mathrm{pH}$ detected in MORB-hosted hydrothermal fluids, two primary possibilities are suggested: (1) the existence of highly altered basement rock lacking the ability to buffer the solution $\mathrm{pH}$ and (2) the presence of ammonium $\left(\mathrm{NH}_{3} / \mathrm{NH}_{4}{ }^{+}\right)$, serving to buffer the $\mathrm{pH}$ at a higher level (German and Von Damm 2004). However, these explanations seem to be unlikely for the Solitaire fluids because (a) the low accumulation of sulfide structures and lack of inactive chimneys imply a relatively young age of the hydrothermal field, and (b) there is no sedimentary component that could produce ammonium in the hydrothermal fluids. Instead, the relatively low temperature $\left(<300{ }^{\circ} \mathrm{C}\right)$ of the Solitaire vent fluids measured at the seafloor suggests another possibility, i.e., that subseafloor mixing between hydrothermal fluids and seawater causes the relatively high $\mathrm{pH}$ value of these fluids. The Solitaire fluids exhibit a content of chlorinities that is approximately $10 \%$ lower than the ambient seawater, indicating subseafloor phase separation and segregation of a vapor-rich phase in the discharging fluids. As all of the other CIR hydrothermal systems (Kairei, Edmond, and Dodo fields) exhibit brine-rich hydrothermal fluids with higher chlorinity than the ambient seawater, this constitutes the first observation of discharges of vapor-rich hydrothermal fluids in the Indian Ocean. Despite the vapor enrichment of the Solitaire fluids, their $\mathrm{H}_{2}$ concentrations (up to $0.46 \mathrm{mmol} / \mathrm{L}$ ) are generally comparable with typical MOR hydrothermal fluids (McCollom 2008). In addition, similar to the Dodo fluids, the hydrothermal fluids from the Solitaire field are also characterized by a high $\mathrm{K} / \mathrm{Cl}$ ratio relative to typical MORB-hosted hydrothermal fluids. Indeed, the basement MORB of the Solitaire hydrothermal field is reported to be influenced by the plume components from the Réunion hot spot and, thus, enriched in alkaline and alkaline earth elements (Murton et al. 2005). Therefore, the high $\mathrm{K} / \mathrm{Cl}$ ratio of the Solitaire fluids is also likely to reflect the chemical characteristic of the plume-influenced MORB at the base of the hydrothermal fields, as in the Dodo hydrothermal field. Because the available hydrothermal fluid samples from the Solitaire field are very limited and the detailed chemical properties of these fluids are still largely unknown, detailed ongoing and future studies of hydrothermal fluid chemistry will provide important insights into the question of how the large- and local-scale geological settings of the Solitaire field affect its unique hydrothermal fluid chemistry.

The maximum temperature of the Edmond hydrothermal fluids $\left(382^{\circ} \mathrm{C}\right)$ (Gallant and Von Damm 2006) is the hottest temperature ever measured in Indian Ocean hydrothermal vents. The $\mathrm{pH}$ values of the Edmond fluids range from 2.97 to 3.3 (Gallant and Von Damm 2006; Kumagai et al. 2008), which are slightly lower than the Dodo, Solitaire, and Kairei fluids, but still within the range of typical MORB-hosted hydrothermal fluids (Gallant and Von Damm 2006). The Edmond fluids are characterized by quite high $\mathrm{Cl}$ concentrations, which are $>70 \%$ higher than in the local ambient seawater, indicating subseafloor phase separation and subsequent brine condensation. The water depth of the Edmond hydrothermal field is $\sim 3,300 \mathrm{~m}$, which corresponds to a hydrostatic pressure of 330 bar. This pressure at the seafloor is above the critical pressure of seawater, indicating that the phase separation of these fluids must occur under supercritical conditions. Furthermore, the data suggest that the temperature of the Edmond fluids must have exceeded $420{ }^{\circ} \mathrm{C}$ to have undergone phase separation, even just below the seafloor. In spite of the notable brine enrichment detected, the $\mathrm{H}_{2}$ concentrations found in the Edmond fluids (0.055-0.111 mmol/kg) (Gallant and Von Damm 2006; Kumagai et al. 2008) are comparable to those of typical MORB-hosted hydrothermal fluids observed elsewhere along the EPR and Mid-Atlantic Ridge (MAR). The vapor and brine phases produced through phase separation are known to be chemically very different from each other and from their parent fluid (e.g., gases are enriched in the vapordominated phase and depleted in the brine-dominated phase) (Butterfield et al. 2003). The parent fluid of the Edmond fluids is therefore considered to be more enriched in gases. In contrast to gaseous species, dissolved species that are primarily ionic (e.g., $\mathrm{Na}^{+}, \mathrm{Cl}^{-}$) are known to show a very strong affinity for the brine phase as a result of phase separation. Indeed, conspicuous enrichment of ionic species was observed in the Edmond fluids (Gallant and Von Damm 2006; Kumagai et al. 2008). However, the Edmond fluids are also characterized by alkali element-to- $\mathrm{Cl}$ ratios that are similar to those of typical MORB-hosted hydrothermal fluids (Gallant and Von Damm 2006; Kumagai et al. 2008). Kumagai et al. (Kumagai et al. 2008) reported the chemical composition of the basement basalt of the Edmond hydrothermal field, showing that the contents of alkaline and alkaline earth elements in the Edmond basalt are almost the same as those typically found in MORB (Sun and McDonough 1989).

In the Kairei hydrothermal field, the maximum temperature of the fluid was reported to be $369{ }^{\circ} \mathrm{C}$ at the Kali vent 
(Kumagai et al. 2008). The pH levels in these high-temperature fluids (3.34 to 3.6) are comparable with those of typical MORB-hosted hydrothermal fluids (Gallant and Von Damm 2006; Kumagai et al. 2008). The $\mathrm{Cl}$ concentrations in the endmember fluids are significantly (up to $\sim 14 \%$ ) greater than in the local ambient seawater, suggesting subseafloor phase separation and brine-phase enrichment. The first report of the chemical compositions of the Kairei hydrothermal fluids, by Gamo et al. (Gamo et al. 2001), noted a marked similarity between the Kairei fluids and other typical MORB-hosted hydrothermal fluids found along the EPR and MAR (Gamo et al. 2001). However, subsequent studies revealed distinct features of the Kairei hydrothermal fluids (Van Dover et al. 2001), including extraordinarily high $\mathrm{H}_{2}$ concentrations, of $2.5-8.5 \mathrm{mmol} /$ $\mathrm{kg}$, compared to the concentrations found in typical MORBhosted hydrothermal fluids (Van Dover et al. 2001; Takai et al. 2004a; Gallant and Von Damm 2006; Kumagai et al. 2008). $\mathrm{H}_{2}$-enriched, high-temperature hydrothermal vent fluids, similar to the Kairei fluids, have been reported from several hydrothermal vent fields located along the MAR (e. g., the Rainbow, Logatchev I and II, Ashaze I and II, and Nibelungen fields) (Charlou et al. 2002, 2008; Melchert et al. 2008). It has generally been accepted that the $\mathrm{H}_{2}$ enrichment of hydrothermal vent fluids is attributed to serpentinization of ultramafic rocks (e.g., abyssal peridotite) (Charlou et al. 2002; Douville et al. 2002). However, there was no geological evidence indicating the presence of ultramafic rocks at or near the Kairei hydrothermal field found in the initial investigation (Van Dover et al. 2001; Gallant and Von Damm 2006). Moreover, the Kairei hydrothermal fluids exhibit $\mathrm{CH}_{4}$ and $\mathrm{Si}$ concentrations that are similar to those reported in typical MOR hydrothermal fluids (Gallant and Von Damm 2006), although the peridotite-hosted hydrothermal fluids observed along the MAR generally exhibit higher $\mathrm{CH}_{4}$ and lower Si concentrations compared to typical basalt-hosted fluids (e.g., Charlou et al. 2002).

In 2006, detailed geological and geophysical investigations were conducted around the Kairei hydrothermal field using the HOV Shinaki 6500 and R/V Yokosuka (YK05-16 cruise). During the research cruise, serpentinized gabbroic rocks (troctolite) were discovered at small topographic highs referred to as the Uraniwa Hills, $\sim 15 \mathrm{~km}$ east of the Kairei hydrothermal field (Kumagai et al. 2008). Nakamura et al. (2009) performed geochemical reaction path model calculations to examine whether the reaction of seawater with the troctolitic rocks exposed in the vicinity of the Kairei hydrothermal field explains the high $\mathrm{H}_{2}$ concentration measured in the hydrothermal fluids. The model results showed that the serpentinization of the Uraniwa troctolite can produce more than $16 \mathrm{mmol} / \mathrm{kg}$ of
$\mathrm{H}_{2}$, similar to the $\mathrm{H}_{2}$ concentrations detected in vent fluids derived from host basement rocks dominated by peridotite (Charlou et al. 2002; Schmidt et al. 2007). To explain the concentrations of the major dissolved components of the vent fluids other than $\mathrm{H}_{2}$, Nakamura et al. (2009) produced an additional geochemical reaction path model incorporating both troctolite and basalt. The model calculations showed the following two results: (1) even limited interaction between the hydrothermal fluids (reacted with troctolite) and the basaltic wall rock could produce a high- $\mathrm{SiO}_{2}$ content, similar to those found in basalt-hosted hydrothermal fluids; and (2) $\mathrm{H}_{2}$ is not predicted to decrease notably during interactions with small amounts of basalt in a hydrothermal upflow zone. This basalt-troctolite hybrid model revealed that troctolite-seawater interactions in recharge and/or reaction zones are responsible for the remarkably high $\mathrm{H}_{2}$ concentrations observed in the Kairei fluids, whereas the concentrations of other dissolved components of the vent fluids are controlled by the interactions with basalt in the subseafloor hydrothermal fluid flows (particularly in the discharge zone).

The low $\mathrm{CH}_{4}$ concentration in the Kairei fluids cannot be explained by the hybrid model. Nakamura et al. (2009) noted that the Ni concentrations in olivine-rich gabbroic rocks (e. g., troctolite) are significantly lower than are found in typical mantle peridotite. Because the amount of $\mathrm{Ni}-\mathrm{Fe}$ alloy directly affects the reaction kinetics of the reduction of $\mathrm{CO}_{2}$ to $\mathrm{CH}_{4}$ (Horita and Berndt 1999), the lower concentrations of $\mathrm{Ni}$ would reduce the catalytic rate of Fischer-Tropsch-type (FTT) or Sabbatier synthesis in the Uraniwa-Hills rocks, resulting in the lower concentrations of $\mathrm{CH}_{4}$ relative to $\mathrm{H}_{2}$ found in the Kairei fluids. However, it should be noted that even in typical peridotite-hosted hydrothermal systems, the $\mathrm{CH}_{4}$ concentrations are not in equilibrium with the concentrations of $\mathrm{H}_{2}$ and $\mathrm{CO}_{2}$, and the real processes controlling $\mathrm{CH}_{4}$ concentrations in hydrothermal fluids remain uncertain.

The Kairei fluids are also characterized by relatively low ratios of alkaline and alkaline earth elements-to-Cl compared with typical MORB-hosted hydrothermal fluids (Gallant and Von Damm 2006). Kumagai et al. (2008) noted the role of the chemical composition of basement rocks. It is well known that ultramafic rocks (including olivine-rich gabbroic rocks) are depleted in alkaline and alkaline earth elements compared to basaltic rocks. Furthermore, the basaltic rocks present around the Kairei hydrothermal field are also unusually depleted in these elements (Kumagai et al. 2008). Therefore, the chemical characteristics of the Kairei fluids are likely associated with the unique lithology of the Kairei hydrothermal field (involvement of olivine-rich gabbroic rocks and highly depleted basalt). 


\subsection{Biological Studies Conducted at the Four Hydrothermal Vent Fields}

\subsubsection{Microbial Communities and Microorganisms Isolated from the CIR Hydrothermal Systems}

Among the four deep-sea hydrothermal systems explored along the CIR, only the Kairei field has been extensively studied with respect to the development of the deep-sea vent microbial community. In this section, we therefore summarize the results of the microbiological investigations conducted at the Kairei hydrothermal field thus far. Comprehensive characterizations of the microbial communities in hydrothermal fluids, chimney structures, and planktonic habitats in the mixing zones between the hydrothermal fluids and ambient seawater have been conducted in the Kairei field (Takai et al. 2004a, b; Suzuki et al. 2004; Nakagawa et al. 2004). In addition to microbial community development, the potential biogeochemical functions related to the subseafloor hydrothermal fluid flows and the associated microbial populations have also been addressed in a series of geomicrobiological and biogeochemical investigations (Takai et al. 2004a, 2006; Nakamura et al. 2009; Kawagucci et al. 2010).

The Kairei hydrothermal system exhibits slightly different hydrothermal fluid endmembers, influenced by subseafloor phase separation (Gallant and Von Damm 2006). The Kali vent site is a principal hydrothermal vent site hosting slightly brine-rich fluid, whereas the Fugen chimney site displays relatively gas-rich endmember fluid (Takai et al. 2004a; Gallant and Von Damm 2006). The Fugen chimney is located in the easternmost part of the hydrothermal field and is likely derived from the longest branched hydrothermal fluid path in the predicted subseafloor hydrogeologic structure (Gallant and Von Damm 2006). Although the Fugen chimney fluid is generally enriched with various gas components, the concentration of $\mathrm{H}_{2}$ in the Fugen chimney fluid is lower than that in the Kali vent fluid (Takai et al. 2004a). The stable isotopic signatures of $\delta \mathrm{D}\left(\mathrm{H}_{2}\right), \delta^{13} \mathrm{C}\left(\mathrm{CO}_{2}\right)$, and $\delta^{13} \mathrm{C}\left(\mathrm{CH}_{4}\right)$ vary between the Kali and Fugen hydrothermal fluids (Takai et al. 2004a; Kawagucci et al. 2010). Together with the observed variation in concentrations, the low $\delta \mathrm{D}\left(\mathrm{H}_{2}\right)$ value in the Fugen chimney fluid indicates a lower temperature isotopic equilibrium, likely promoted by microbial $\mathrm{H}_{2}$ consumption. In addition, the high $\delta^{13} \mathrm{C}\left(\mathrm{CO}_{2}\right)$ value in the Fugen chimney fluid may be explained by isotopic fractionation during microbial consumption, and the significantly low $\delta^{13} \mathrm{C}$ $\left(\mathrm{CH}_{4}\right)$ level in the Fugen fluid can be attained only through microbial methanogenesis (Takai et al. 2004a). All of these geochemical results are consistent with the composition and metabolic activity of the subseafloor microbial communities revealed through the microbiological characterization of the components entrained from the hydrothermal fluids (Takai et al. 2004a).

The microbial communities in the hydrothermal fluids and the chimney structures of the Kali and Fugen sites were characterized through the quantitative cultivation technique, $16 \mathrm{~S}$ rRNA gene clone analysis, and FISH analysis (Takai et al. 2004a). Among the microbial communities trapped in the Kali vent and Fugen chimney fluids (the insitu-colonization-system communities), members of Thermococcus and Pyrococcus represented the most abundant cultivated populations. The second most abundant cultivated population consisted of thermophilic and hyperthermophilic Methanococcales members, all of which represented hydrogenotrophic $\left(\mathrm{H}_{2}\right.$-trophic), methanogenic chemolithoautotrophs. The other cultivated microbial components were thermophilic and hyperthermophilic members of Aquifex and Persephonella (both $\mathrm{H}_{2}$-trophic and/or thiotrophic chemolithoautotrophs) and Archaeoglobus (organotrophic and $\mathrm{H}_{2}$-trophic, $\mathrm{SO}_{4}$-reducing chemolithotrophs). Thermodesulfatator species were reported to be the dominant, $\mathrm{H}_{2}$-trophic $\mathrm{SO}_{4}$-reducing chemolithoautotrophic bacteria in the chimney microbial communities of the Kairei field (Moussard et al. 2004). In addition, certain populations of mesophilic and thermophilic Epsilonproteobacteria, such as Hydrogenimonas and Sulfurimonas, were found in the Fugen chimney fluids. These Epsilonproteobacteria are also $\mathrm{H}_{2}$-trophic and thiotrophic chemolithoautotrophs. The microbial communities found in the Fugen chimney habitats were very similar to the community in the Fugen chimney fluid (Takai et al. 2004a).

Culture-independent molecular analyses (16S rRNA gene cloning and FISH analyses) have generally revealed similar compositions of the microbial communities found in the hydrothermal fluids and chimney structures (Takai et al. 2004a). However, FISH analysis clearly demonstrated the numerical predominance of Methanococcales populations in the microbial communities of the Kali and Fugen fluids and strongly suggested that hyperthermophilic $\mathrm{H}_{2}$-trophic methanogens sustain the microbial communities as primary producers (Takai et al. 2004a). Thus, both geochemical and microbiological characterizations have pointed to the possible existence of a hyperthermophilic subsurface lithotrophic microbial ecosystem (HyperSLiME) beneath the Kairei hydrothermal field (Takai et al. 2004a).

In contrast to the microbial communities that are closely associated with the high-temperature hydrothermal fluid emissions of the Kairei field, the planktonic microbial communities found in the hydrothermal plumes and habitats in the vicinity of this field were not significantly different from those observed in other deep-sea hydrothermal environments (Takai et al. 2004b). Based on examination of the relative abundance of Marine Group I (Creanarchaeota 
and Epsilonproteobacteria) populations in the planktonic microbial communities of the hydrothermal plumes, the communities in the Kairei field showed much less abundant Epsilonproteobacteria populations compared to the Iheya North field of the Okinawa Trough. However, microbial populations other than Marine Group I, such as the SUP05 group Gammaproteobacteria, a cosmopolitan microbial population that dominates hydrothermal plume communities (Sunamura et al. 2004; Dick and Tebo 2010), were not quantitatively estimated (Takai et al. 2004b). In addition, La Duc et al. (et al. 2007) reported that many of the heterotrophic bacteria isolated from the Kairei hydrothermal plumes displayed high multi-stressor tolerance to desiccation, peroxide exposure, and UV and gamma ray irradiation. However, it is still unclear whether this finding is specifically attributed to the microbial communities of the Kairei hydrothermal plumes or to global hydrothermal plume environments.

In the Edmond field, the microbial community of a sulfide chimney was characterized only via culture-independent, PCR-mediated 16S rRNA gene phylotype analysis (Hoek et al. 2003). The results of this analysis do not provide a quantitative estimation of the microbial community composition or potential functions and represent only qualitative compositional features. Compared to the $16 \mathrm{~S}$ rRNA gene phylotype compositions obtained from various chimney habitats of the Kairei field, the phylotype composition in the Edmond sulfide chimney, exhibiting relatively hightemperature fluid, consisted mainly of bacterial phylotypes, such as Epsilonproteobacteria and Aquificales, and archaeal phylotypes, such as the Aciduliprofundus and Thermococcus genera (Hoek et al. 2003). These phylotypes were quite different from the phylotype compositions found in the Kairei chimneys and fluids, which were dominated by hydrogenotrophic Methanococales and sulfate-reducing chemolithotrophs (Takai et al. 2004a). Although quantitative characterization of the viable populations and metabolic functions of the microbial communities found in various Edmond hydrothermal field habitats remains to be conducted, the different patterns of the microbial phylotype compositions between the Kairei and the Edmond hydrothermal fields are likely associated with the different energy states of the microbially habitable (mixing) zones. These zones are primarily controlled by the physical and chemical characteristics of the endmember hydrothermal fluids, as suggested by Takai and Nakamura (2010, 2011).

Despite the poorly delimited patterns of microbial community development, many novel deep-sea vent microorganisms have been successfully isolated from the CIR deep-sea hydrothermal systems, likely due to the previously unexplored biogeographicity of these systems. Immediately after the discovery of the Kairei hydrothermal field, many new genera and species of deep-sea vent chemolithoautotrophs were isolated and described (L'Haridon et al. 2003; Moussard et al. 2004; Takai et al. 2004c, d, 2008). A hyperthermophilic hydrogenotrophic methanogen, Methanocaldococcus indicus (L'Haridon et al. 2003), and an extremely thermophilic hydrogenotrophic methanogen, Methanotorris formicicus (Takai et al. 2004c), identified in the Kairei hydrothermal field represent new species of Methanococcales and important primary producers of chemolithotrophic microbial communities. A thermophilic hydrogenotrophic sulfatereducer, Thermodesulfatator indicus (Moussard et al. 2004), and a thermophilic hydrogenotrophic epsilonproteobacterium, Hydrogenimonas thermophila (Takai et al. 2004d), were new genera of deep-sea vent chemolithoautotrophs originally found in the CIR Kairei field. In addition, although it was not a new taxon of methanogen, the most hyperthermophilic living form identified thus far, Methanopyrus kandleri strain 116, was obtained from the Kairei hydrothermal fluid (Takai et al. 2008). The identification of such new taxa of deep-sea vent microorganisms was likely associated with the newly explored biogeographicity of CIR hydrothermal systems, and the unique physiological traits of these chemolithoautotrophs are related to the unique geological setting and hydrothermal fluid chemistry of the Kairei field.

\subsubsection{Hydrothermal Vent Fauna and Chemosynthetic Symbioses}

The Kairei and Edmond fields have been found to host novel genera and families that are potentially indigenous to CIR hydrothermal systems as well as faunal species common to the Pacific and the Atlantic Oceans (Hashimoto et al. 2001; Van Dover et al. 2001). Based on the limited data obtained from these two hydrothermal vent sites, recent statistical work addressing the connections among biogeographical provinces (Bachraty et al. 2009) and population connectivities (Vrijenhoek 2010) has highlighted similarities between western Pacific and Indian Ocean vent communities. However, as the authors noted, the available information on the Indian Ocean hydrothermal vent faunas is still scarce, and additional faunal data from new Indian Ocean hydrothermal systems is required to improve our knowledge of the biodiversity and biogeography of the global deep-sea hydrothermal vent fauna. During the TAIGA project, we discovered and investigated two new hydrothermal vent sites, the Dodo and Solitaire fields (Nakamura et al. 2012), providing novel information about hydrothermal vent-endemic fauna in the Indian Ocean. The details regarding recent progress in understanding the distribution and genetic diversity of hydrothermal vent fauna and biogeographical and genetic population connectivities in the CIR hydrothermal systems are presented elsewhere in this book (Watanabe and Beedessee, Chap. 16). Here, we briefly 
describe the results of the biological studies conducted at the CIR hydrothermal vent fields.

An important finding among the Indian Ocean vent fauna was the existence of two morphotypes of a "scaly-foot" gastropod. Since its first discovery in the Kairei hydrothermal field in 2001 (Van Dover et al. 2001), this gastropod has attracted particular attention because of its distinct features, including unusual black-colored iron sulfide dermal sclerites (Warén et al. 2003; Suzuki et al. 2006), an iron sulfide-plated armor shell structure (Yao et al. 2010), and the unique endoand epi-symbioses found in its enlarged esophageal gland and sclerites, respectively (Goffredi et al. 2004). In October 2009, during the YK-09-13 cruise, a new morphotype of scaly-foot gastropod was found at the Solitaire hydrothermal field, which exhibits similar morphological and anatomical features to the previously reported type that inhabits the Kairei field but completely lacks an iron sulfide coating on its sclerites (Nakamura et al. 2012).

The new morphotype displays a brown shell and creamcolored sclerites, in contrast to the metallic black shell and sclerites of the type previously known from the Kairei field. Indeed, the sclerites of the Kairei morphotype exhibit the presence of a thick coating of iron sulfide minerals (e.g., greigite or pyrite), as previously reported (Warén et al. 2003; Suzuki et al. 2006), whereas no specific condensation of $\mathrm{Fe}$ and $\mathrm{S}$ was identified on the sclerites of the Solitaire morphotype. Surprisingly, however, phylogenetic and haplotype analyses clearly demonstrated that the two morphotypes of scaly-foot gastropod of different colors are genetically indistinguishable and should be classified as the same species (Nakamura et al. 2012). Furthermore, the noniron-sulfide-mineralized sclerites of the Solitaire morphotype show greater mechanical strength of the overall structure compared to those of the Kairei morphotype (Nakamura et al. 2012), despite the fact that the iron sulfide mineralization of sclerites of the Kairei morphotype is believed to harden the sclerites for protection from predation (Suzuki et al. 2006). These findings from the new morphotype of the scaly-foot gastropod demonstrate that the mechanisms and physiological roles of iron sulfide mineralization are still fully uncertain.

A nutritional symbiotic relationship with chemosynthetic bacteria was also observed in the Kairei morphotype of the scaly-foot gastropod (Goffredi et al. 2004). There were different types of symbioses identified in different tissues, such as endosymbiosis of gammaproteobacterium in the greatly enlarged esophageal gland and episymbiosis of Epsilonproteobacteria and Deltaproteobacteria on the iron sulfidecoated sclerites. The nutritional transfer between the chemosynthetic symbiont and the host gastropod is likely sustained by the endosymbiosis in the esophageal gland (Goffredi et al. 2004). Very recently, the complete genome of a gammaproteobacterial endosymbiont found in the Kairei morphotype of the scaly-foot gastropod has been determined (Nakagawa et al. 2013). Notable findings from this study include the presence and transcription of genes for flagellar assembly, through which proteins are potentially exported from the symbiont to the host (Nakagawa et al. 2013). This result indicates the possible nutritional transfer mechanism of this chemosynthetic symbiosis. In addition, the extremely low genetic individuality in the endosymbionts suggests that stringent symbiont selection by the Kairei morphotype of the scaly-foot gastropod prevents random genetic drift in the small population of horizontally transmitted symbionts (Nakagawa et al. 2013). The genomic analysis of the symbiont also suggested that the chemosynthetic symbiosis found in the Kairei morphotype of the scaly-foot gastropod was relatively recently established (Nakagawa et al. 2013).

Another novel chemosynthetic symbiosis was found in a hydrothermal vent gastropod (Alviniconcha aff. hessleri) predominantly living in the diffusing fluid flow zones of the Kairei field (Suzuki et al. 2005). Alviniconcha gastropods belonging to the family Provannidae inhabit deep-sea hydrothermal fields at the margins of the western and southwestern Pacific Ocean and along the CIR (Warén and Bouchet 2001; Nakamura et al. 2012). In the gills of the Alviniconcha gastropods from the Kairei field, an epsilonproteobacterial endosymbiont was identified for the first time using molecular ecological techniques. It was found that primary production by this species likely supports the nutrition of the host Alviniconcha gastropod (Suzuki et al. 2005). The complete genome of the Alviniconcha gastropod is being determined, and the energy, carbon metabolism, and nutritional transfer mechanisms of this symbiosis are being investigated through polyphasic physiological and molecular characterizations. The genetic evolution and ecophysiological functions of the chemosynthetic symbiosis found in the Alviniconcha gastropods will be clarified through multiple approaches in the future.

\subsection{Future Prospects}

During the TAIGA project, the exploration and assessment of four Indian Ocean hydrothermal vent fields, including two newly discovered hydrothermal fields, were significantly advanced. As shown in this paper, the results of these investigations greatly extend our knowledge of the geochemical variations of hydrothermal activity and their relationships to the geological background as well as the biodiversity and biogeography of the hydrothermal ventassociated microbial and faunal communities in the Indian Ocean. . The four studied hydrothermal vent sites were all located within the CIR; however, two other MORs in the Indian Ocean (Southeast Indian Ridge: SEIR and Southwest Indian Ridge: SWIR) remain to be explored. 
Very recently, a new hydrothermal vent site was discovered along the SWIR and was explored by a Chinese scientific team (Tao et al. 2012). They found hydrothermal ventendemic fauna, including scaly-foot gastropods at the vent site. However, the fluid chemistry and geological background of this site are still unknown, and detailed descriptions of the vent fauna have yet to be published. Moreover, several hydrothermal plumes indicating the existence of unseen hydrothermal vent sites have also been detected not only at the SWIR (German et al. 1998) but also at the SEIR (Wang et al. 2011). Because similarity between the Indian Ocean and Western Pacific Ocean vent communities has been noted by several researchers, the discovery and investigation of hydrothermal vent sites along the SEIR (a possible corridor for vent communities between Indian and Western Pacific Oceans) are particularly important. In the future, detailed geological, geochemical, and geophysical investigations as well as physiological, genetic, and trophic characterizations of hydrothermal vent-endemic fauna in uninvestigated hydrothermal vent sites will certainly provide important information contributing to our understanding the Indian Ocean MOR hydrothermal system and its relationship to the Pacific and Atlantic Ocean MOR hydrothermal systems.

Acknowledgments We would like to thank the two anonymous reviewers for their constructive and helpful comments and suggestions. This research was financially supported by the Ministry of Education, Culture, Science, and Technology (MEXT) of Japan, through a special coordination fund (Project TAIGA: Trans-crustal Advection and In situ biogeochemical processes of Global subseafloor Aquifer).

Open Access This chapter is distributed under the terms of the Creative Commons Attribution Noncommercial License, which permits any noncommercial use, distribution, and reproduction in any medium, provided the original author(s) and source are credited.

\section{References}

Bachraty C, Legendre P, Desbruyeres D (2009) Biogeographic relationships among deep-sea hydrothermal vent faunas at global scale. Deep Sea Rese I 56:1371-1378

Butterfield DA, Seyfried Jr. WE, Lilley MD (2003) Composition and evolution of hydrothermal fluids. In: Halbach PE, Tunnicliffe V, Hein JR (eds) Energy and mass transfer in marine hydrothermal systems. Dahlem University Press, Dahlem, pp 123-161

Cannat M, Sauter D, Mendel V, Ruellan E, Okino K, Escartin J, Combier V, Baala M (2006) Modes of seafloor generation at a melt-poor ultraslow-spreading ridge. Geology 34:605-608

Charlou JL, Donval JP, Fouquet Y, Jean-Baptiste P, Holm N (2002) Geochemistry of high $\mathrm{H}_{2}$ and $\mathrm{CH}_{4}$ vent fluids issuing from ultramafic rocks at the Rainbow hydrothermal field $\left(36^{\circ} 14^{\prime} \mathrm{N}, \mathrm{MAR}\right)$. Chem Geol 191:345-359

Charlou JL, Donval JP, Konn C, Birot D, Sudarikov S, Jean-Baptiste P, Fouquet Y, Scientific Party of the SERPENTINE Cruise (2008) High hydrogen and abiotic hydrocarbons from new ultramafic hydrothermal sites between $12^{\circ} \mathrm{N}$ and $15^{\circ} \mathrm{N}$ on the Mid Atlantic
Ridge-Results of the SERPENTINE cruise. EOS Trans AGU, 88, Fall Meet Suppl, Abstract T51F-04

Corliss JB, Dymond J, Gordon LI, Edmond JM, Von Herzen RP, Ballard RD, Green K, Williams D, Bainbridge A, Crane K, van Andel TH (1979) Submarine thermal springs on the Galapagos Rift. Science 203:1073-1083

DeMets C, Gordon RG, Argus DF, Stein S (1994) Effect of recent revisions to the geomagnetic reversal time scale on estimates of current plate motions. Geophys Res Lett 21:2191-2194

Dick GJ, Tebo BM (2010) Microbial diversity and biogeo- chemistry of the Guaymas Basin deep-sea hydrothermal plume. Environ Microbiol 12:1334-1347

Douville E, Charlou JL, Oelkers EH, Bienvenu P, Jove Colon CF, Donval JP, Fouquet Y, Prieur D, Appriou P (2002) The rainbow vent fluids $\left(36^{\circ} 14^{\prime} \mathrm{N}, \mathrm{MAR}\right)$ : the influence of ultramafic rocks and phase separation on trace metal content in Mid-Atlantic Ridge hydrothermal fluids. Chem Geol 184:37-48

Edmond JM, Measure CI, McDuff RE, Chan LH, Collier R, Grant B, Gordon LI, Corliss JB (1979) Ridge crest hydrothermal activity and the balances of the major and minor elements in the ocean: the Galapagos data. Earth Planet Sci Lett 46:1-18

Edmond JM, Von Damm KL, McDuff RE, Measure CI (1982) Chemistry of hot springs on the East Pacific Rise and their effluent dispersal. Nature 297:187-191

Elderfield H, Schultz A (1996) Mid-ocean ridge hydrothermal fluxes and the chemical composition of the ocean. Annu Rev Earth Planet Sci 24:191-224

Escartin J, Mevel C, MacLeod CJ, McCaig AM (2003) Constraints on deformation conditions and the origin of oceanic detachements: The Mid-Atlantic Ridge core complex at $15^{\circ} 45^{\prime} \mathrm{N}$. Geochem Geophys Geosyst 4:1067. doi:10.1029/2002GC000472

Gallant RM, Von Damm KL (2006) Geochemical controls on hydrothermal fluids from the Kairei and Edmond Vent Fields, $23^{\circ}-25^{\circ} \mathrm{S}$, Central Indian Ridge. Geochem Geophys Geosyst 7, Q06018. doi:10.1029/2005GC001067

Gamo T, Nakayama E, Shitashima K, Isshiki K, Obata H, Okamura K, Kanayama S, Oomori T, Koizumi T, Matsumoto S, Hasumoto H (1996) Hydrothermal plumes at the Rodriguez Triple Junction, Indian Ridge. Earth Planet Sci Lett 142:261-270

Gamo T, Chiba H, Yamanaka T, Okudaira T, Hashimoto J, Tsuchida S, Ishibashi J, Kataoka S, Tsunogai U, Okamura K, Sano Y, Shinjo R (2001) Chemical characteristics of newly discovered black smoker fluids and associated hydrothermal plumes at the Rodriguez Triple Junction. Central Indian Ridge Earth Planet Sci Lett 193:371-379

German CR, Von Damm KL (2004) Hydrothermal processes. In: Turekian KK, Holland HD (eds) The oceans and marine geochemistry, treatise on geochemistry, vol 6. Elsevier, New York, pp 181-222

German CR, Baker ET, Mevel C, Tamaki K, the FUJI Science Team (1998) Hydrothermal activity along the southwest Indian ridge. Nature 395:490-493

German CR, Connelly DP, Evans AJ, Murton BJ, Curewitz D Okino K, Statham PJ, Parson LM (2001) Hydrothermal activity along the Central Indian Ridge: ridges, hotspots and philately. Eos Trans AGU 82(47), Fall Meet Suppl, Abstract OS42E-06

Goffredi SK, Warén A, Orphan VJ, Van Dover CL, Vrijenhoek RC (2004) Novel forms of structural integration between microbes and a hydrothermal vent gastropod from the Indian Ocean. Appl Environ Microb 70:3082-3090

Hashimoto J, Ohta S, Gamo T, Chiba H, Yamaguchi T, Tsuchida S, Okudaira T, Watabe H, Yamanaka T, Kitazawa M (2001) First hydrothermal vent communities from the Indian Ocean discovered. Zool Sci 18:717-721

Hekinian R (1982) Petrology of the ocean floor, Elsevier Oceanography Series, 33, Elsevier, Amsterdam, 393 pp 
Herzig PM, Plüger WL (1988) Exploration for hydrothermal activity near the Rodriguez Triple Junction, Indian Ocean. Can Mineral 26:721-736

Hoek J, Banta A, Hubler F, Reysenbach A-L (2003) Microbial diversity of a sulphide spire located in the Edmond deep-sea hydrothermal vent field on the Central Indian Ridge. Geobiology 1:119-127

Horita J, Berndt ME (1999) Abiogenic methane formation and isotopic fractionation under hydrothermal conditions. Science 285:1055-1057

Jannasch HW, Mottl MJ (1985) Geomicrobiology of deep-sea hydrothermal vents. Science 229:717-725

Jean-Baptiste P, Mantisi F, Pauwells H, Grimaud D, Patriat P (1992) Hydrotheramal ${ }^{3} \mathrm{He}$ and manganese plumes at $19^{\circ} 29^{\prime} \mathrm{S}$ on the Central Indian Ridge. Geophys Res Lett 19:1787-1790

Kawagucci S, Okamura K, Kiyota K, Tsunogai U, Sano Y, Tamaki K, Gamo T (2008) Methane, manganese, and helium-3 in newly discovered hydrothermal plumes over the Central Indian Ridge, $18^{\circ}-20^{\circ} \mathrm{S}$. Geochem Geophys Geosyst 9, Q10002. doi:10.1029/ 2008GC002082

Kawagucci S, Toki T, Ishibashi J, Takai K, Ito M, Oomori T, Gamo T (2010) Isotopic variation of molecular hydrogen in $20-375{ }^{\circ} \mathrm{C}$ hydrothermal fluids as detected by a new analytical method. J Geophys Res 115, G03021

Kumagai H, Nakamura K, Toki T, Morishita T, Okino K, Ishibashi J, Tsunogai U, Kawagucci S, Gamo T, Shibuya T, Sawaguchi T, Neo N, Joshima M, Sato T, Takai K (2008) Geological background of the Kairei and Edmond hydrothermal fields along the Central Indian Ridge: implications of their vent fluids' distinct chemistry. Geogluids 8:239-251

La Duc MT, Benardini JN, Kempf MJ, Newcombe DA, Lubarsky M, Venkateswaran K (2007) Microbial diversity of Indian Ocean hydrothermal vent plumes: microbes tolerant of desiccation, peroxide exposure, and ultraviolet and gamma-irradiation. Astrobiology 7:416-431

L'Haridon S, Reysenbach A-L, Banta A, Messner P, Schumann P, Stackebrandt E, Jeanthon C (2003) Methanocaldococcus indicus sp. nov., a novel hyperthermophilic methanogen isolated from the Central Indian. Ridge Int J Syst Evol Microbiol 53:1931-1935

McCollom TM (2008) Observation, experimental, and theoretical constraints on carbon cycling. In: Lowell RP, Seewald JS, Metaxas A, Perfit MR (eds) Magma to microbe: modeling hydrothermal processes at Ocean spreading center. AGU Monograph, vol 178. American Geophysical Union, Washington, DC, pp 193-213

Melchert B, Devey CW, German CR, Lackschewitz KS, Seifert R, Walter M, Mertens C, Yoerger DR, Baker ET, Paulick H, Nakamura K (2008) First evidence for high-temperature off-axis venting of deep crustal/mantle heat: the Nibelungen hydrothermal field, southern Mid-Atlantic Ridge. Earth Planet Sci Lett 275:61-69

Moussard H, L'Haridon S, Tindall BJ, Banta A, Schumann P, Stackebrandt E, Reysenbach A-L, Jeanthon C (2004) Thermodesulfatator indicus gen. nov., sp. nov., a novel thermophilic chemolithoautotrophic sulfate-reducing bacterium isolated from the Central Indian. Ridge Int J Syst Evol Microbiol 54:227-233

Murton BJ, Tindle AG, Milton JA, Sauter D (2005) Heterogeneity in southern Central Indian Ridge MORB: implications for ridge-hot spot interaction. Geochem Geophys Geosys 6:Q03E20, doi:10. 1029/2004GC000798

Nakagawa T, Nakagawa S, Inagaki F, Takai K, Horikoshi K (2004) Phylogenetic diversity of sulfate-reducing prokaryotes in active deep-sea hydrothermal vent chimney structures. FEMS Microbiol Lett 232:145-152

Nakagawa S, Shimamura S, Takaki Y, Suzuki Y, Murakami S, Watanabe T, Fujiyoshi S, Mino S, Sawabe T, Maeda T, Makita H, Nemoto S, Nishimura S, Watanabe H, Watsuji T, Takai K (2013) Allying with armored snails: the complete genome of gammaproteobacterial endosymbiont. ISME J. doi:10.1038/ismej.2013.131
Nakamura K, Morishita T, Bach W, Klein F, Hara K, Okino K, Takai K, Kumagai H (2009) Serpentinized troctolites exposed near the Kairei Hydrothermal Field, Central Indian Ridge: insights into the origin of the Kairei hydrothermal fluid supporting a unique microbial ecosystem. Earth Planet Sci Lett 280:128-136

Nakamura K, Watanabe H, Miyazaki J, Takai K, Kawagucci S, Noguchi T, Nemoto S, Watsuji T, Matsuzaki T, Shibuya T, Okamura K, Mochizuki M, Orihashi Y, Ura T, Asada A, Marie D, Koonjul M, Singh M, Beedessee G, Bhikajee M, Tamaki K (2012) Discovery of new hydrothermal activity and chemosynthetic fauna on the Central Indian Ridge at $18^{\circ}-20^{\circ} \mathrm{S}$. PLoS One 7:e32965. doi:10.1371/journal.pone.0032965

Nauret F, Abouchami W, Galer SJG, Hofmann AW, Hémond C, Chauvel C, Dyment J (2006) Correlated trace element-Pb isotope enrichments in Indian MORB along $18-20^{\circ} \mathrm{S}$, Central Indian Ridge. Earth Planet Sci Lett 245:137-152

Nealson KH, Inagaki F, Takai K (2005) Hydrogen-drien subsurface lithoautotrophic microbial ecosystems (SLiMEs): do they exist and why should we care? Trends Microbiol 13:405-410

Palmer MR, Edmond JM (1989) The strontium budget of the modern ocean. Earth Planet Sci Lett 92:11-26

Plüger WL, Herzig PM, Becker KP, Deissmann G, Schöps D, Lange J, Jenisch A, Ladage S, Richnow HH, Schulze T, Michaelis W (1990) Discovery of hydrothermal fields at the Central Indian Ridge. Mar Min 9:73-86

Schmidt K, Koschinsky A, Garbe-Schönberg D, de Carvalho LM, Seifert R (2007) Geochemistry of hydrothermal fluids from the ultramafic-hosted Logatchev hydrothermal field, $15^{\circ} \mathrm{N}$ on the MidAtlantic Ridge: temporal and spatial investigation. Chem Geol 242:1-21

Sun S-S, McDonough WF (1989) Chemical and isotopic systematics of oceanic basalts: implications for mantle composition and processes. In: Saunders AD, Norry MJ (eds) Magmatism in the ocean basins, vol 42. Geological Society of London Special Publication, London, pp 313-345

Sunamura M, Higashi Y, Miyako C, Ishibashi J, Maruyama A (2004) Two bactetia phylotypes are predominant in the Suiyo Seamount hydrothermal plume. Appl Environ Microbiol 70:1190-1198

Suzuki Y, Inagaki F, Takai K, Nealson KH, Horikoshi K (2004) Microbial diversity in inactive chimney structures from deep-sea hydrothermal systems. Microbial Ecol 47:186-196

Suzuki Y, Sasaki T, Suzuki M, Nogi Y, Miwa T, Takai K, Nealson KH, Horikoshi K (2005) Novel chemoautotrophic endosymbiosis between a member of the Epsilonproteobacteria and the hydrothermal vent gastropod Alviniconcha aff. hessleri (Gastropoda: Provannidae) from the Indian Ocean. Appl Environ Microbiol 71:5440-5450

Suzuki Y, Kopp RE, Kogure T, Suga A, Takai K, Tsuchida S, Ozaki N, Endo K, Hashimoto J, Kato Y, Mizota C, Hirata T, Chiba H, Nealson KH, Horikoshi K, Kirschvink JL (2006) Sclerite formation in the hydrothermal-vent "scaly-foot" gastropod-possible control of iron sulfide biomineralization by the animal. Earth Planet Sci Lett 242:39-50

Takai K (2011) Limits of life and biosphere: Lesson from detection of microorganisms in deep-sea and deep subsurface in the Earth. In: Gargaud M, Lopez-Garcia P, Martin H (eds) Origins and evolution of life: an astrobiological perspective. Cambridge Univeristy Press, Cambridge, pp 469-486

Takai K, Nakamura K (2010) Compositional, physiological and metabolic variability in microbial communities associated with geochemically diverse, deep-sea hydrothermal vent fluids. In: Barton LL, Mandl M, Loy A (eds) Geomicrobiology: molecular and environmental perspective. Springer, Berlin, pp 251-283

Takai K, Nakamura K (2011) Archaeal diversity and community development in deep-sea hydrothermal vents. Curr Opin Microbiol $14: 282-291$ 
Takai K, Gamo T, Tsunogai Y, Nakayama N, Hirayama H, Nealson KH, Horikoshi K (2004a) Geochemical and microbiological evidence for a hydrogen-based, hyperthermophilic subsurface lithoautotrophic microbial ecosystem (HyperSLiME) beneath an active deep-sea hydrothermal field. Extremophiles $8: 269-282$

Takai K, Oida H, Suzuki Y, Hirayama H, Nakagawa S, Nunoura T, Inagaki F, Nealson KH, Horikoshi K (2004b) Spatial distribution of marine crenarchaeota group I in the vicinity of deep-sea hydrothermal systems. Appl Environ Microbiol 70:2404-2413

Takai K, Nealson KH, Horikoshi K (2004c) Methanotorris formicicus sp. nov., a novel extremely thermophilic, methane-producing archaeon isolated from a black smoker chimney in the Central Indian Ridge. Int J Syst Evol Microbiol 54:1095-1100

Takai K, Nealson KH, Horikoshi K (2004d) Hydrogenimonas thermophila gen. nov., sp. nov., a novel thermophilic, hydrogenoxidizing chemolithoautotroph within the $\varepsilon$-Proteobacteria, isolated from a black smoker in a Central Indian Ridge hydrothermal field. Int J Syst Evol Microbiol 54:25-32

Takai K, Nakamura K, Suzuki K, Inagaki F, Nealson KH, Kumagai H (2006) Ultramafics-Hydrothermalism-Hydrogenesis-HyperSLiME $\left(\mathrm{UltraH}^{3}\right)$ linkage: a key insight into early microbial ecosystem in the Archean deep-sea hydrothermal systems. Paleontol Res 10:269-282

Takai K, Nakamura K, Toki T, Tsunogai U, Miyazaki M, Miyazaki J, Hirayama H, Nakagawa S, Nunoura T, Horikoshi K (2008) Cell proliferation at $122{ }^{\circ} \mathrm{C}$ and isotopically heavy $\mathrm{CH}_{4}$ production by a hyperthermophilic methanogen under high-pressure cultivation. Proc Natl Acad Sci U S A 105:10949-10954

Tao C, Lin J, Guo S, Chen YJ, Wu G, Han X, German CR, Yoerger DR, Zhou N, Li H, Su X, Zhu J, the DY115-19 (Legs 1-2) and DY115-20 (Legs 4-7) Science Parties (2012) First active hydrothermal vents on an ultraslow-spreading center: Southwest Indian Ridge. Geology 40:47-50

Van Dover CL, Humphris SE, Fornari D, Cavanaugh CM, Collier R, Goffredi SK, Hashimoto J, Lilley MD, Reysenbach AL, Shank TM, Von Damm KL, Banta A, Gallant RM, Gotz D, Green D, Hall J, Harmer TL, Hurtado LA, Johnson P, McKiness ZP, Meredith C, Olson E, Pan IL, Turnipseed M, Won Y, Young III CR, Vrijenhoek RC (2001) Biogeography and ecological setting of Indian Ocean hydrothermal vents. Science 294:818-823

Van Dover CL, German CR, Speer KG, Parson LM, Vrijenhoek RC (2002) Evolution and biogeograpy of deep-sea vent and seep invertebrates. Science 295:1253-1257

Von Damm KL, Edmond JM, Measures CI, Grant B (1985a) Chemistry of submarine hydrothermal solutions at $21^{\circ} \mathrm{N}$. East Pacific Rise Geochim Cosmochim Acta 49:2197-2220

Von Damm KL, Edmond JM, Measures CI, Grant B (1985b) Chemistry of submarine hydrothermal solutions at Guaymas Basin. Gulf California Geochim Cosmochim Acta 49:2221-2237

Vrijenhoek RC (2010) Genetic diversity and connectivity of deep-sea hydrothermal vent metapopulations. Mol Ecol 19:4391-4411

Wang T, Chen YJ, Tao C (2011) Revisit the K-segment of the Southeast Indian Ridge for new evidence of hydrothermal plumes. Chin Sci Bull 56:3605-3609

Warén A, Bouchet P (2001) Gastropoda and monoplacophora from hydrothermal vents and seeps: new taxa and records. Veliger 44:116-231

Warén A, Bengtson S, Goffredi SK, Van Dover CL (2003) A hot-vent gastropod with iron sulfide dermal sclerites. Science 302:1007

Yao H, Dao M, Imholt T, Huang J, Wheeler K, Bonilla A, Suresh S, Ortiz C (2010) Protection mechanisms of the iron-plated armor of a deep-sea hydrothermal vent gastropod. Proc Natl Acad Sci U S A 107:987-992 